ZOOLOGIA 31 (5): 435-444, October, 2014

http://dx.doi.org/10.1590/S1984-46702014000500004

\title{
Use of food resources by small fish species in Neotropical rivers: responses to spatial and temporal variations
}

\author{
Jislaine Cristina da Silva ${ }^{1,3}$, Éder André Gubiani² \& Rosilene Luciana Delariva ${ }^{1}$
}

\author{
${ }^{1}$ Programa de Pós-Graduação em Conservação e Manejo de Recursos Naturais, Universidade Estadual do Oeste do Paraná. \\ Rua Universitária 2069, Caixa postal 711. 85819-110 Cascavel, Paraná, Brazil. \\ 2 Programa de Pós-Graduação em Conservação e Manejo de Recursos Naturais e Programa de Pós-Graduação em Recursos \\ Pesqueiros e Engenharia de Pesca, Grupo de pesquisas em Recursos Pesqueiros e Limnologia, Universidade Estadual do Oeste \\ do Paraná. Rua da Faculdade 645, Jardim Santa Maria, 85903-000 Toledo, Paraná, Brazil. \\ ${ }^{3}$ Corresponding author. E-mail: jislainebio@yahoo.com.br
}

\begin{abstract}
Spatial and temporal variations in food supply play a crucial role in the determination of the patterns of food use by fish species. This study evaluated spatial and temporal variations in food utilization by small fish species of the Verde River, Upper Paraná River Basin, state of Mato Grosso do Sul, Brazil. Samplings were conducted in the rainy and dry periods, from November 2010 to August 2012, using trawls, cast nets and gillnets, in nine sampling sites grouped into three biotopes: upstream and downstream of the Branca Waterfall, and tributary. The stomach contents of 3,263 individuals of 12 small species were examined according to the volumetric method. Altogether, 31 food items were identified. Overall seed consumption was greater in the rainy period, and the consumption of terrestrial plants was greater in the dry period. Hymenoptera was an important item in the diet, but the proportions in the consumption of this item was different between biotopes and periods. The consumption of Coleoptera and Isoptera was expressive only downstream of the Branca Waterfall in the rainy period, and aquatic plant was mostly consumed in the tributary in the dry period. Significant differences were detected in the diet composition between biotopes, hydrological periods and also the interaction between these two factors. Allochthonous resources were clearly the most consumed by the species in all biotopes, especially during the rainy period. The dietary overlap between species, although showing significant spatial and temporal differences, was low (0.4) for about $60 \%$ of species pairs. Thus, it is concluded that spatial and temporal changes in the utilization of food resources by small fish were related to physiographic differences of the channel and the surroundings, which contributed to the significance of seasonal changes in the diet, also reflecting the low dietary overlap between species.
\end{abstract}

KEY WORDS. Allochthonous resources; diet; fish fauna; seasonality; Upper Paraná River Basin.

Spatial and temporal heterogeneity is a dominant and outstanding characteristic of most ecosystems (HоLт 2002). Ecologists recognize that these spatial and temporal variations play a key role in both environmental characteristics (with the biological communities directly interfering with biodiversity patterns), and in the processes through which populations persist, for instance food webs, species interactions and coexistence (Pouls et al. 1996, 1997, Holt 2002, Berg \& Bengtsson 2007).

Considering that trophic relationships may be influenced by environmental changes over time and space (Brose et al. 2005), studies developed in aquatic environments focusing on resource use by fish species are considered important for unraveling the dynamics of these changes. According to YANG et al. (2008), biological communities are governed by spatial and seasonal variations in food availability. Thus, information on this variability enables us to assess the behavior of fish populations over time and space.
In tropical aquatic environments, spatial variations can be associated with differences in species richness and habitat heterogeneity, including the physiography of the channel and its surroundings (Winemiller \& Pianka 1990). On the other hand, seasonality results mainly from the annual cycles of temperature, rainfall and water levels, which cause cyclical changes in the abundance and availability of food resources (LoweMcConnel 1999, Abujanra et al. 2009). All these factors influence the availability of food resources in aquatic ecosystems, and interfere with the input of allochthonous and autochthonous items (DAviEs et al. 2008), playing a key role in the spatial and temporal patterns of fish feeding (Prejs \& Prejs 1987, Winemiller \& WinemilLer 2003).

In addition to local environmental conditions and their temporal variability, one must take into account the intrinsic characteristics of each species. Though Neotropical fish are characterized by high trophic plasticity (GERKING 1994, AвELHA et al.

2014 Sociedade Brasileira de Zoologia | www.sbzoologia.org.br | www.scielo.br/zool All content of the journal, except where identified, is licensed under a Creative Commons attribution-type BY-NC. 
2001), other factors such as selectivity, motility, energetic and physiological requirements may allow exploitation of resources at different spatial and seasonal scales (MASDEU et al. 2011, UIEDA $\&$ PINTO 2011). Thus the use of resources by fish may be related to resource accessibility in the environment, and the active choices and feeding preferences of each species according to their trophic niches or foraging areas (WINEMILLER \& JePSEN 1998, AHrEns et al. 2012). These mechanisms, coupled with food availability, can reduce dietary overlap, which can also vary spatially and temporally (ZaReT \& RAND 1971, Esteves \& GaletTI 1995).

The influence of spatial and seasonal changes in trophic relationships has been recognized for a long time (ARgERMEIER 1982, Schoener 1989, Polis et al. 1996, 1997, Hahn et al. 1997, Winemiller \& Jepsen 1998, Holt 2002) and has gained importance recently in the ecological context (GIMENEs et al. 2010, CorrêA et al. 2011, РetTit et al. 2011, Ромвo et al. 2013, WolfF et al. 2013). However, some aspects that influence the availability of resources along spatial gradients and aspects related to seasonality need to be further clarified. The river continuum concept emphasizes that spatial and temporal changes in biological processes, food availability and ecosystem functioning occur along the course of rivers (VANOTTE et al. 1980). However, some geographic features such as barriers to dispersal, floodplains and confluence of tributaries may create a discontinuous river. In the main channel they can increase habitat heterogeneity along the river continuum, which is extremely important in the maintenance of aquatic communities (PERRY \& SChaeffer 1987, Rice et al. 2001, Benda et al. 2004, Gubiani et al. 2010). Environmental degradation of watersheds in recent years, coupled with the special factors already mentioned, have led to changes in the characteristics of the surroundings of many rivers, affecting their input of food resources and cyclical patterns over time.

The number of publications concerning the diet and trophic structure of the fish fauna of the Paraná River Basin has increased in recent years (HAHN et al. 1997, LIMA-Junior \& Goitein, 2004, Viana et al. 2006, Hahn \& Fugi 2007, Abunjara et al. 2009, Bennemann et al. 2011, Viana et al. 2013). However, very few studies have been conducted in the part of the basin that includes areas of the Cerrado. Given the possibility of the construction of dams in the region in the near future, now is the time to analyze the variations in the trophic ecology of the fish species in these natural environments.

In this context, this study hypothesized that the discontinuity of the river, caused by a natural geographical barrier, maximizes the habitat heterogeneity along the channel, which together with the confluence of tributaries and seasonal water regime, influences the trophic dynamics of the riverine environment. The objective of this study was to evaluate the spatial and temporal variations in the utilization of food resources by small fish species of the Verde River, Upper Paraná River Basin, state of Mato Grosso do Sul, addressing specifically the following questions: 1) Do spatial variations occur in the use of food resources by small fish species in different biotopes, and hydrological periods (rainy and dry seasons)? 2) Do the origins of the food used by the species also vary seasonally and spatially? 3) Is dietary overlap between species reflected by spatial and temporal variations?

\section{MATERIAL AND METHODS}

The drainage area of the Verde River $\left(20^{\circ} 40^{\prime} 30.61^{\prime \prime} S\right.$, $53^{\circ} 34^{\prime} 4.91^{\prime \prime} \mathrm{W}$ ) is located in the Brazilian Cerrado, and stands out as an important tributary of the Upper Paraná River (Fig. 1). The Verde River Basin is located in the state of Mato Grosso do Sul and covers areas of the municipalities of Camapuã, Costa Rica, Água Clara, Ribas do Rio Pardo, Brasilândia, and Três Lagoas. Its mouth is located in the Paraná River, at the reservoir of the hydroelectric power plant Sérgio Mota (Porto Primavera), the state of São Paulo. The climate is characterized by two distinct seasons: dry winters (April to September) and rainy summers (October to March) (Ribeiro \& Walter 1998, Pagotto \& Souza 2006).

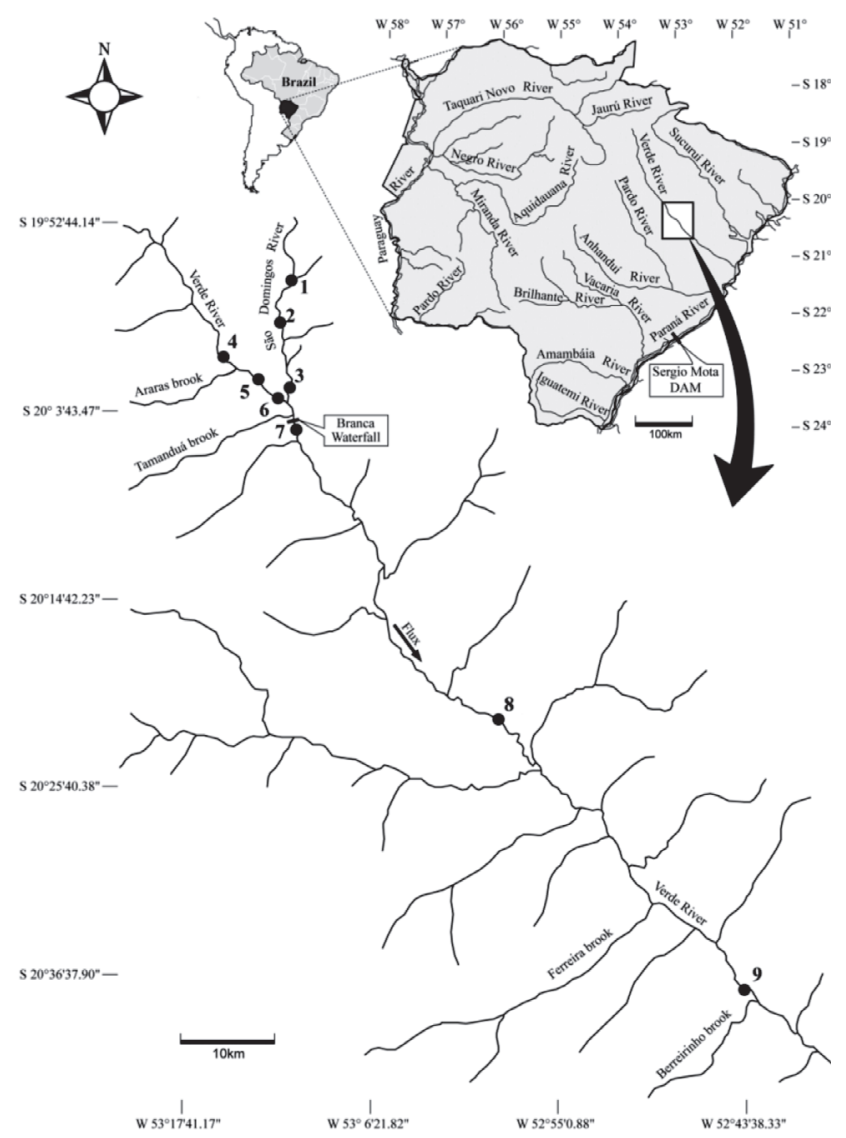

Figure 1. Study area and sampling sites in the Verde and São Domingos Rivers, Upper Paraná River Basin, Mato Grosso do Sul, Brazil. 
In the stretch we studied the Verde River has a natural geographical barrier, the Branca Waterfall, which is considered a small barrier to fish dispersal. This waterfall is characterized by turbulent waters and extensive rapids. Thus, it was considered as barrier separating the sites evaluated, since the characteristics of the main channel differ upstream and downstream of this waterfall in size, depth and number of tributaries. (Table I).

Nine sampling sites were established, distributed in the Verde River and one of its major tributaries, the São Domingos River (Fig. 1). In order to assess spatial changes in the use of food resources by fish species, the sites were pooled in three different biotopes as a function of their distinct characteristics: tributary $(1,2,3)$, channel upstream of the Branca Waterfall $(4,5,6)$ and channel downstream of the Branca Waterfall $(7,8,9)$ (Fig. 1). The physical characteristics of each site are described in Table I.

Fish sampling was performed monthly during the rainy period, from November 2010 to March 2011 and October 2011 to February 2012, and quarterly in the dry period, from May to August 2011 and 2012 (Fig. 2), totaling 14 months of collecting. The following fishing devices were used: trawls, cast nets and gillnets with simple mesh of $2.4,3,4,5,6,7,8,9,10,12$, 14 , and $16 \mathrm{~cm}$ and trammel nets (locally known as feiticeiras) with mesh of 6,7 , and $8 \mathrm{~cm}$ between non-adjacent knots, with $1.5 \mathrm{~m}$ in height and $20 \mathrm{~m}$ in length in the Verde River and 10 $\mathrm{m}$ in length in the tributary. After capturing the fish, we anesthetized them with a benzocaine solution $(250 \mathrm{mg} / \mathrm{l})$ following the American Veterinary Medical Association (Avma 2001), fixed them in plastic bags containing formaldehyde $10 \%$ and placed them in polyethylene containers. In the laboratory, we identified the fish following Graça \& Pavanelli (2007), measured (total and standard length in $\mathrm{cm}$ ), and weighed them (g). We preserved vouchers of each species in alcohol 70\% and deposited them in the ichthyological collection of the Núcleo de Pesquisas em Limnologia, Ictiologia e Aquicultura (Nupélia), Universidade Estadual de Maringá (available at http://peixe. nupelia.uem.br).

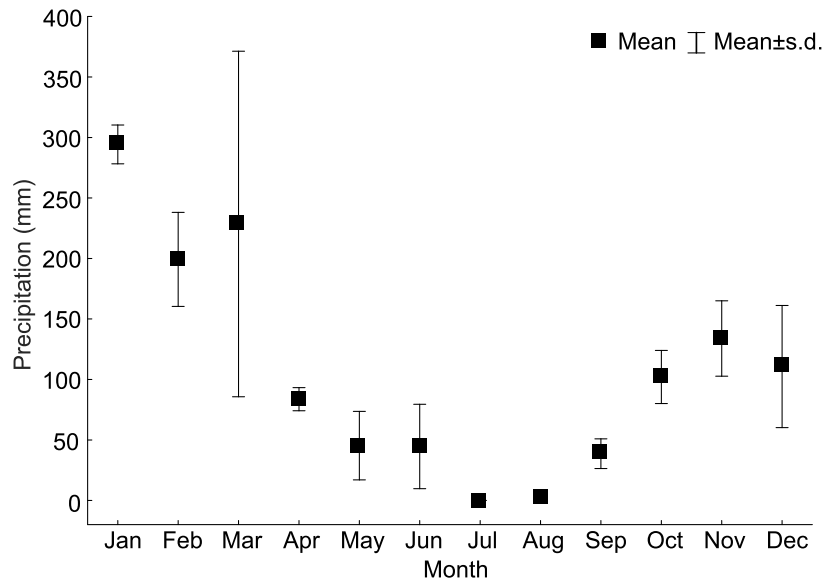

Figure 2. Variation the mean of monthly rainfall in the studied stretch of the Verde River and its tributary, Upper Paraná River Basin, Brazil, from 2010 to 2012. Data were provided by the Brazilian National Water Agency (ANA) (station of the Upper Verde River).

Only small species (those in which the adults have standard length less than $15 \mathrm{~cm}$ ) were used for the analysis of stomach contents, as proposed by CASTRO et al. (2003), with number of stomachs $>10$. The stomachs analyzed were those with a degree of repletion greater than $50 \%$ of fullness (for scale, see Zavala-Camin 1996). Stomach contents were examined using an optical microscope and a stereoscopic. The food items were identified using Bicudo \& BICUdo (1970) for algae and MugnaI et al. (2010) for invertebrates, and other specific literature when necessary. The items were quantified according to the volumetric method (HysLop 1980) where total volume of a food item taken by the fish population is given as a percentage of the total volume of all stomach contents. We use graduated tubes and a glass counting plate for, measure the volume of items (Hellawell \& Abel 1971).

To summarize the diet composition data for each species, the values of volume of food items were evaluated by a

Table I. Physical characteristics of the sampling sites in the Verde River and São Domingos, Upper Paraná River Basin, state of Mato Grosso do Sul, Brazil.

\begin{tabular}{|c|c|c|c|c|c|}
\hline Sampling sites & Biotopes & $\begin{array}{l}\text { Predominant } \\
\text { substrate }\end{array}$ & Riparian vegetation & Channel physiography & Surroundings \\
\hline $\begin{array}{l}\text { 1, 2, } 3 \text { (São } \\
\text { Domingos River) }\end{array}$ & $\begin{array}{l}\text { Tributaries (above } \\
\text { Branca Waterfall) }\end{array}$ & Sandy/rocky & $\begin{array}{l}\text { Native riparian vegetation } \\
\text { (shrubby) with } 10 \text { m in width, } \\
\text { on average; some sites lack } \\
\text { vegetation and are eroded (on } \\
\text { the left margin of the site } 1 \\
\text { with over } 500 \mathrm{~m} \text { of vegetation) }\end{array}$ & $\begin{array}{l}\text { Approximately width of } 10 \text { to } 20 \\
\text { m, with rapids, some backwater } \\
\text { areas, and shelters on the } \\
\text { margins. Regions with small } \\
\text { marginal lagoons and floodplains. } \\
\text { Some stretches with low depth }\end{array}$ & Livestock activity \\
\hline 4, 5, 6 (Verde River) & $\begin{array}{l}\text { Upstream of the } \\
\text { Branca Waterfall }\end{array}$ & Rocky/sandy & $\begin{array}{l}\text { Preserved region with native } \\
\text { riparian vegetation (shrubby) } \\
\text { with } 20 \text { to } 30 \mathrm{~m} \text { in width on } \\
\text { both margins }\end{array}$ & $\begin{array}{l}\text { Width between } 40 \text { and } 150 \mathrm{~m} \text {, } \\
\text { with rapid waters, few backwater, } \\
\text { and shelter sites. Some marginal } \\
\text { lagoons and floodplain areas }\end{array}$ & $\begin{array}{l}\text { Extensive livestock farming } \\
\text { and eucalyptus plantation }\end{array}$ \\
\hline 7, 8, 9 (Verde River) & $\begin{array}{l}\text { Downstream of the } \\
\text { Branca Waterfall }\end{array}$ & Rocky/sandy & $\begin{array}{l}\text { Native riparian vegetation } \\
\text { (shrubby) with } 10 \mathrm{~m} \text { in width, } \\
\text { on average }\end{array}$ & $\begin{array}{l}\text { Width between } 40 \text { and } 60 \text { m, } \\
\text { with fast and turbulent waters, } \\
\text { rapids and small waterfalls, and } \\
\text { large floodplain regions }\end{array}$ & $\begin{array}{l}\text { Large farms with extensive } \\
\text { livestock farming in the } \\
\text { surroundings }\end{array}$ \\
\hline
\end{tabular}


principal coordinate analysis (PCoA; LEGENDRE \& LEGENDRE 1998), using a Bray-Curtis similarity matrix with 9,999 randomizations. PCoA is a generalization of principal component analysis, in which the eigenvalues are extracted from a similarity or distance matrix (MANLY 1994, Jongman et al. 1995). The main advantage is that it can be applied when the relationships between variables are not linear. Axes with positive eigenvalues were retained for interpretation (BorCARD et al. 2011). To test possible significant differences in species diet composition between pre-defined groups (biotopes and hydrological periods), we used a permutational multivariate analysis of variance (PERMANOVA; Anderson 2001). The indicator value method (IndVal; Dufrêne \& Legendre 1997) was employed to determine food items that were significant at each biotope and hydrological periods.

To determine the origin of food resources consumed by fish species, the items were grouped into allochthonous, autochthonous, and indeterminate, for each biotope and hydrological period. In order to test the difference between the proportions of allochthonous and autochthonous items, between sites and hydrological periods, we used the chi-square test $\left(\chi^{2}\right)$. The resources of undetermined origin were not considered in this analysis because it represented less than $1 \%$ of the diet composition of all species.

To analyze the pattern of dietary overlap, a matrix based on the volumetric abundance of food items was calculated for each sample (site/month) using the overlap index of PIANKA (1973), which is described by the equation:

$$
O_{j k}=\frac{\sum_{i}^{n} P_{i j} \times P_{i k}}{\sqrt{\sum_{\mathrm{i}}^{\mathrm{n}} P_{\mathrm{ij}}^{2} \times \sum_{\mathrm{i}}^{\mathrm{n}}{P_{\mathrm{ik}}^{2}}^{2}}}
$$

The overlap values range from 0 (no overlap) to 1 (complete overlap), and were set at the following levels: low (0.00$0.39)$, intermediate (0.4-0.6) and high (0.6-1.0), modified from Grossman (1986) by CorrêA et al. (2011).

A null model (HaRvey et al. 1983) was used to assess the significance of the Pianka index. In this procedure, the observed percentages of food categories were randomized 10,000 times within each sample and for each randomization the Pianka index was calculated. For this analysis, we used the scrambled zeros algorithm (RA3), which retains the niche breadth of the species observed, but allows the use of any resource available in the matrix. The average dietary overlap observed was compared with the average calculated by null models (Winemiller \& Pianka 1990). A nonparametric analysis of variance (Kruskal-Wallis) was applied to test possible differences in dietary overlap values between biotopes. To test differences between periods in each site, we used a t-test.

The PCoA and PERMANOVA were run in the software R (R DeVelopment 2011). IndVal was calculated using the software PC-Ord ${ }^{\circledR} 5.0$ (McCune \& MefFord 2006). Dietary overlap and null model were calculated with the aid of EcoSim ${ }^{\circledR} 7.0$ (GotelLI \& ENTSMINGER 2006). Chi-square, Kruskal-Wallis ANOVA, and ttest were run in the software Statistica ${ }^{\circledR} 7.1$ (STATSOFT 2005). The significance level adopted for all statistical analyses was set at $\mathrm{p}<0.05$.

\section{RESULTS}

Throughout the sampling period, we analyzed the stomach contents of 3,263 individuals belonging to 12 species of small fish (Table II).

Table II. Taxonomic position of the species (Rels et al. 2003), number of stomachs analyzed and size range of the individuals sampled in the Verde River and its tributary, Upper Paraná River Basin, Brazil, from November 2010 to August 2012.

\begin{tabular}{|c|c|c|c|c|c|c|}
\hline \multirow{2}{*}{ Species } & \multirow{2}{*}{$\mathrm{N}$ analyzed stomachs } & \multicolumn{3}{|c|}{ Occurrence } & \multirow{2}{*}{ Standard length range $(\mathrm{cm})$} & \multirow{2}{*}{ Vouchers specimens } \\
\hline & & UBW & DWB & TRI & & \\
\hline \multicolumn{7}{|l|}{ Characiformes: Characidae } \\
\hline Astyanax aff. fasciatus (Cuvier, 1819) & 593 & $\mathrm{x}$ & $\mathrm{x}$ & $\mathrm{x}$ & $1.6-13.5$ & NUP 108 \\
\hline Astyanax aff. paranae Eigenmann, 1914 & 12 & & $x$ & $x$ & $2.0-7.5$ & NUP 133 \\
\hline Astyanax altiparanae Garutti \& Britski, 2000 & 446 & $\mathrm{x}$ & $x$ & $x$ & $1.5-13.0$ & NUP 6149 \\
\hline Aphyocharax dentatus Eigenmann \& Kennedy, 1903 & 22 & & $x$ & & $2.1-4.1$ & NUP 5324 \\
\hline Bryconamericus sp. 1 & 375 & $\mathrm{x}$ & $x$ & $\mathrm{x}$ & $2.1-6.2$ & \\
\hline Bryconamericus stramineus Eigenmann, 1908 & 467 & $\mathrm{x}$ & $\mathrm{x}$ & $\mathrm{x}$ & 1.5-6.1 & NUP 55 \\
\hline Knodus moenkhausii (Eigenmann \& Kennedy, 1903) & 169 & & $\mathrm{x}$ & & $1.7-4.4$ & NUP 4766 \\
\hline Moenkhausia aff. intermedia Eigenmann, 1908 & 183 & $\mathrm{x}$ & $x$ & $x$ & $1.3-6.5$ & NUP 3208 \\
\hline Moenkhausia aff. sanctaefilomenae (Steindachner, 1907) & 14 & $\mathrm{x}$ & $\mathrm{x}$ & $\mathrm{x}$ & $2.0-6.2$ & NUP 371 \\
\hline Piabina argentea Reinhardt, 1867 & 825 & $x$ & $x$ & $x$ & $0.5-7.5$ & NUP 6209 \\
\hline Serrapinnus notomelas (Eigenmann, 1915) & 130 & $x$ & $x$ & $x$ & $1.5-3.2$ & NUP 107 \\
\hline \multicolumn{7}{|l|}{ Siluriformes: Heptapteridae } \\
\hline Pimelodella gracilis (Valenciennes, 1835) & 27 & $\mathrm{x}$ & $\mathrm{x}$ & $\mathrm{x}$ & $2.6-15.0$ & NUP 3118 \\
\hline Total number & 3263 & & & & & \\
\hline
\end{tabular}


Were recorded, in the diet of all species, 31 food items (Appendix S1*). For all biotopes analyzed the consumption of seeds was higher during the rainy period, while terrestrial plants (leaves) were the most consumed item in the dry period. Hymenoptera was an important item in the diet of fish species, but the proportions consumed differed between biotopes and hydrological periods. The highest consumption of this item was observed upstream of the Branca Waterfall in the dry period, and in the tributary, in the rainy period. The consumption of Coleoptera and Isoptera was expressive only downstream of the Branca Waterfall in the rainy period, and aquatic plants were consumed mostly in the tributary in the dry period (Table III).

The principal coordinate analysis (PCoA) summarized the diet composition of the small fish species and showed a trophic segregation between biotopes and hydrological periods. An interaction between these two factors (Fig. 3) was also evidenced. Axes 1 and 2 were retained for interpretation (\% explanation $=24.40 \%$ ). A clear separation was verified in the diet composition, especially between the tributary and upstream and downstream of the Branca Waterfall in both hydrological periods (Fig. 3).

Significant differences in diet composition were detected between biotopes (PERMANOVA; pseudo-F $=0.01, \mathrm{p}<0.01$ ) and hydrological periods (pseudo- $F=0.01, p<0.01$ ). The interaction between factors was also significant (pseudo- $\mathrm{F}=0.01$, $\mathrm{p}<0.01)$. Upstream and downstream of the Branca Waterfall, the items that contributed to this differentiation were of allochthonous origin in the rainy period (seeds, Araneae, Isoptera and Psocoptera), and of autochthonous origin in the dry period (Odonata nymph, Detritus, Plecoptera and Immature Diptera). In turn, in the tributary, the indicator items were registered only in the dry period, primarily of autochthonous origin (Aquatic plant, Ostracoda, Ephemeroptera), except terrestrial plants that are of allochthonous origin (IndVal, p < 0.05 , Table IV).

Allochthonous resources were clearly the most consumed by the species in all biotopes, especially during the rainy period (Fig. 4). In the dry period, the downstream of the Branca Waterfall and in tributaries, the fish species consumed more autochthonous resources. This difference was associated with an increase in the consumption of algae and aquatic vegetation (Table III). Significant differences were observed between the proportions of consumption of allochthonous and autochthonous food items (Chi-square, $\chi^{2}>3.84, \mathrm{p}<0.05$ ).

Overall, dietary overlap between species was low $(<0.40)$ for about $60 \%$ of species pairs (Fig. 5). Significant differences were observed in dietary overlap between biotopes $(H=17.60$, $\mathrm{p}<0.05)$. For hydrological periods, significant differences were found only upstream of the Branca Waterfall $(t=3.12$, $p<$ 0.05). According to the null model of the Pianka index, di-
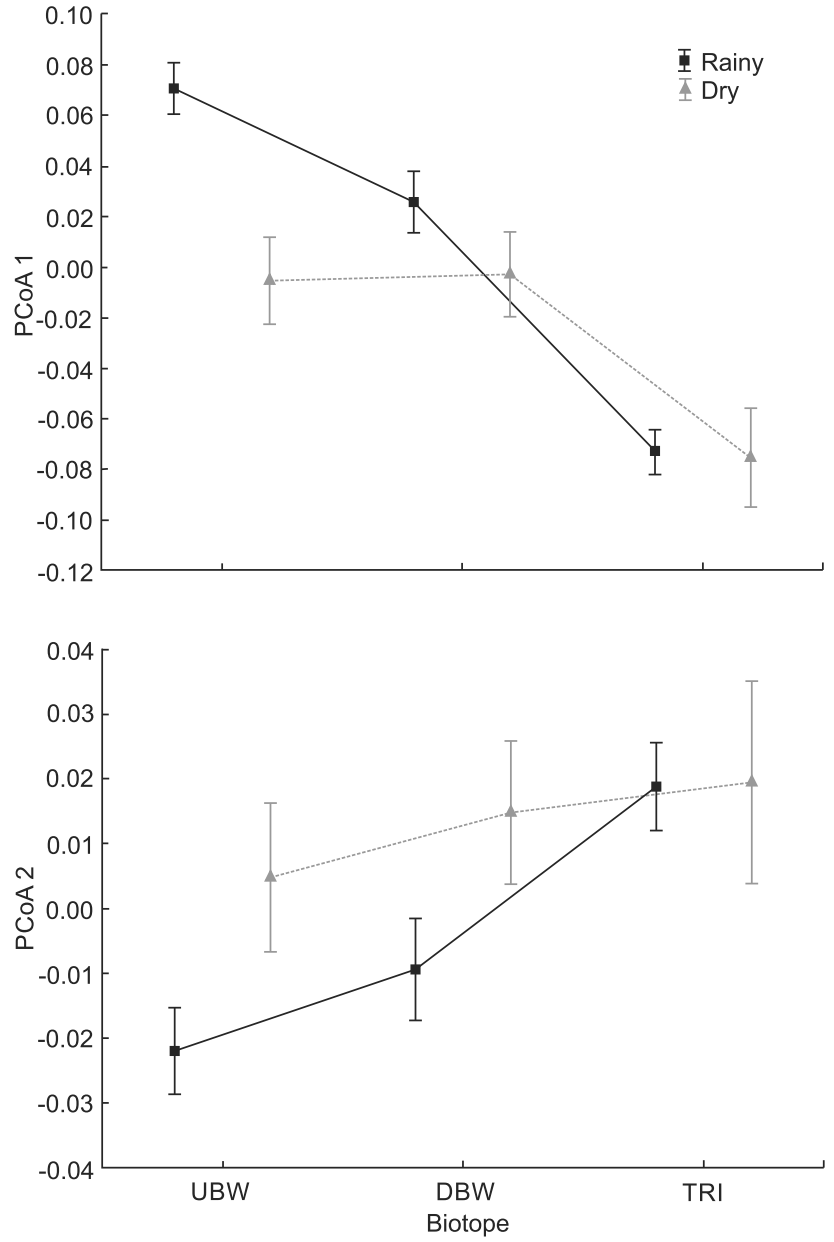

Figure 3. Mean scores ( \pm standard error) of Axis 1 and 2, retained by the Principal Coordinate Analysis (PCoA), according to food items consumed by small-sized fish species sampled in the Verde River, Upper Paraná River Basin, Brazil, from November 2010 to August 2012. Upstream of the Branca Waterfall (UBW), Downstream of the Branca Waterfall (DBW), and Tributary (TRI).

etary overlap values were significantly higher than expected by chance $(\mathrm{p}<0.05)$ in $72 \%$ samples, suggesting that these values are not random and hence represent a real process of resource partitioning between species.

\section{DISCUSSION}

This study shows that the composition of the diet of the small fish species of the Verde River varied in spatial and temporal scales. Segregation in the use of food resources suggests that the supply of these items have been ruled by spatial and

*Available as Online Supplementary Material accessed with the online version of the manuscript at http://www.scielo.br/zool 
Tabela III. Volume percentage of food items consumed by small-sized fish species, classified by origin in each biotope in both hydrological periods, in the Verde River and its tributary, Upper Paraná River Basin, Brazil, from November 2010 to August 2012. Asterisk indicates values below $0.1 \%$. The most consumed food items are in bold. Upstream of the Branca Waterfall (UBW), Downstream of the Branca Waterfall (DBW), and Tributary (TRI).

\begin{tabular}{|c|c|c|c|c|c|c|}
\hline & \multicolumn{2}{|c|}{ UBW } & \multicolumn{2}{|c|}{ DBW } & \multicolumn{2}{|c|}{ TRI } \\
\hline Food items & Rainy & Dry & Rainy & Dry & Rainy & Dry \\
\hline \multicolumn{7}{|l|}{ Autochthonous } \\
\hline Testate Amoebae & * & * & & * & * & * \\
\hline Acarina & * & * & & & & * \\
\hline Amphipoda & * & * & & & & \\
\hline Cladocera & & & 0.2 & & & \\
\hline Ostracoda & & & & & & * \\
\hline Ephemeroptera & 0.5 & 1.3 & 1.1 & 3.5 & 1.4 & 2.8 \\
\hline Odonata nymph & 2.7 & 4.1 & 0.4 & 2.4 & 0.6 & 1.6 \\
\hline Plecoptera & 0.5 & 1.6 & 0.7 & 2.2 & 0.7 & 1.2 \\
\hline Immature Coleoptera & 0.1 & 0.1 & 0.3 & 0.2 & 0.3 & 0.2 \\
\hline Trichoptera & 1.1 & 1.3 & 1.6 & 1.5 & 1.7 & 1.4 \\
\hline Immature Diptera & 0.4 & 0.8 & 0.4 & 4.5 & 0.9 & 1.0 \\
\hline Immature Lepidoptera & 0.1 & 0.8 & 0.4 & 1.1 & 0.3 & * \\
\hline Aquatic insect remains & 2.3 & 2.7 & 1.7 & 3.6 & 2.1 & 2.0 \\
\hline Scales & 0.1 & 0.5 & 1.9 & 0.4 & 0.4 & 1.6 \\
\hline Fish & 0.1 & & 1.6 & & 0.0 & \\
\hline Algae & 3.2 & 5.2 & 0.8 & 7.7 & 3.1 & 5.0 \\
\hline Aquatic plant & 0.8 & 5.3 & * & 5.4 & 2.6 & 14.3 \\
\hline \multicolumn{7}{|l|}{ Allochthonous } \\
\hline Oligochaeta & 3.3 & 1.7 & 0.3 & & 3.6 & \\
\hline Araneae & 0.2 & 0.3 & 1.6 & 0.1 & 0.4 & 0.2 \\
\hline Orthoptera & 3.1 & 1.5 & * & * & 0.8 & 0.3 \\
\hline Isoptera & 2.4 & 1.3 & 10.2 & & 1.8 & \\
\hline Psocoptera & * & * & 0.2 & & * & \\
\hline Hemiptera & 2.3 & 1.2 & 1.3 & 0.6 & 1.6 & 4.9 \\
\hline Homoptera & * & 0.4 & 0.1 & & 0.1 & * \\
\hline Diptera & * & 0.1 & 0.2 & 0.1 & 0.2 & * \\
\hline Hymenoptera & 16.5 & 27.0 & 9.1 & 10.0 & 25.1 & 7.6 \\
\hline Coleoptera & 3.8 & 4.1 & 16.7 & 3.0 & 2.7 & 1.7 \\
\hline Terrestrial insect remains & 1.8 & 2.1 & 0.5 & 0.7 & 1.6 & 0.7 \\
\hline Seeds & 43.3 & 15.3 & 42.5 & 30.2 & 36.4 & 26.1 \\
\hline Terrestrial Plants & 11.5 & 20.2 & 6.2 & 22.6 & 11.2 & 26.8 \\
\hline \multicolumn{7}{|l|}{ Undetermined } \\
\hline Detritus & 0.1 & 1.0 & * & 0.2 & 0.4 & 0.4 \\
\hline
\end{tabular}

seasonal factors, as well the interaction between them. The differences between biotopes upstream and downstream of the Branca Waterfall, both belonging to the main channel of the Verde River, may be related to the heterogeneity of these sites, reflecting the longitudinal pattern of the river and its surround-

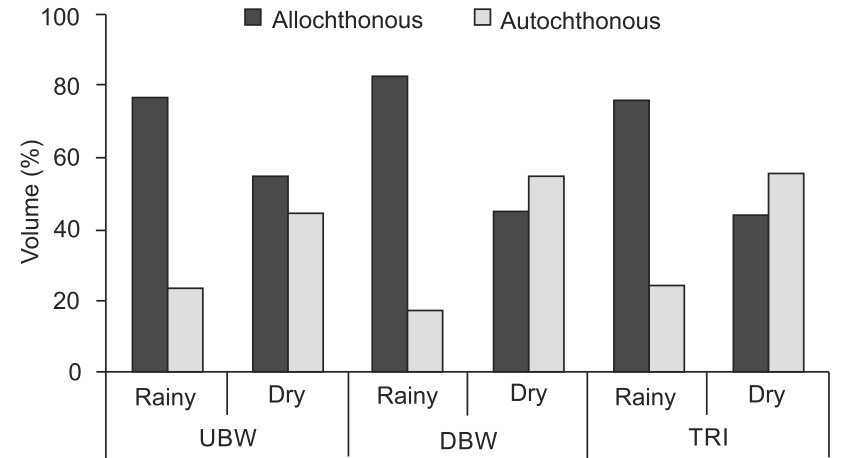

Figure 4. Percentage composition of the origin of food resources consumed by small-sized fish species in the three biotopes in both hydrological periods, Verde River, Upper Paraná River Basin, Brazil, from November 2010 to August 2012. Upstream of the Branca Waterfall (UBW), Downstream of the Branca Waterfall (DBW), and Tributary (TRI).

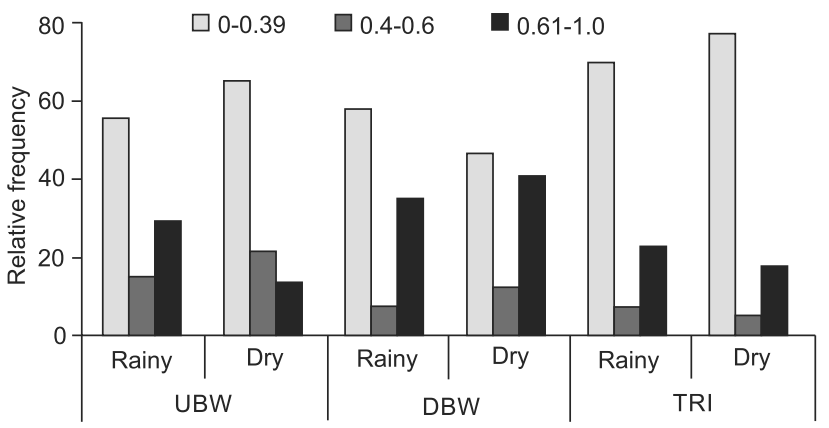

Figure 5. Dietary overlap values of small-sized fish species in each biotope in both hydrological periods, in the Verde River, Upper Paraná River Basin, Brazil, using the Pianka index, from November 2010 to August 2012. Upstream of the Branca Waterfall (UBW), Downstream of the Branca Waterfall (DBW), and Tributary (TRI).

ings. According to the river continuum concept of VANOTTE et al. (1980), natural changes in the physical conditions of rivers from upstream to downstream form a gradient that affects the availability of resources and consequently the trophic relations of fish assemblages. On the other hand, discontinuity, caused mainly by geographical barriers and by confluence with tributaries, can change the characteristics of the channel and maximize the diversity of patterns (Rice et al. 2001, BENDA et al. 2004). This concept can be applied to the biotopes here analyzed.

The stretch located upstream of the Branca Waterfall is characterized by slower water flow, wider channel and more extensive stretches with native riparian vegetation compared to the downstream portion. The downstream stretch is characterized by rocks that form small waterfalls and rapids, it has a narrower and more incised channel, and large areas of wet- 
Tabela IV. Indicator value analysis showing the relative abundance (RA), relative frequency (RF) and indicator value (Indval) of food items consumed by small-sized fish species, discriminated between biotopes and hydrological periods, in the Verde River and its tributary, Upper Paraná River Basin, Brazil, from November 2010 to August 2012. Only items with values significant $(p<0.05)$ by the Monte Carlo test are listed. Upstream of the Branca Waterfall (UBW), Downstream of the Branca Waterfall (DBW), and Tributary (TRI). * indicate item of Allochthonous origin and ${ }^{\circ}$ indicate item of Autochthonous origin.

\begin{tabular}{|c|c|c|c|c|c|c|c|c|}
\hline \multirow{2}{*}{ Biotope } & \multirow{2}{*}{ Food item } & \multicolumn{2}{|c|}{ RA\% } & \multicolumn{2}{|c|}{ RF\% } & \multicolumn{2}{|c|}{ Indval } & \multirow{2}{*}{$\mathrm{p}$} \\
\hline & & Rainy & Dry & Rainy & Dry & Rainy & Dry & \\
\hline \multirow[t]{3}{*}{ UBW } & Seeds* & 26 & & 57 & & 15 & & $<0.01$ \\
\hline & Odonata nymph ${ }^{\circ}$ & & 32 & & 14 & & 5 & $<0.01$ \\
\hline & Detritus $^{\circ}$ & & 46 & & 7 & & 2 & 0.03 \\
\hline \multirow[t]{5}{*}{ DBW } & Araneae* & 59 & & 5 & & 3 & & 0.04 \\
\hline & Isoptera* & 66 & & 11 & & 7 & & $<0.01$ \\
\hline & Psocoptera* & 86 & & 3 & & 2 & & $<0.01$ \\
\hline & Plecoptera $^{\circ}$ & & 23 & & 14 & & 3 & 0.04 \\
\hline & Immature Diptera ${ }^{\circ}$ & & 44 & & 34 & & 15 & $<0.01$ \\
\hline \multirow[t]{4}{*}{ TRI } & Aquatic plant ${ }^{\circ}$ & & 55 & & 13 & & 7 & $<0.01$ \\
\hline & Ostracoda ${ }^{\circ}$ & & 100 & & 1 & & 1 & $<0.01$ \\
\hline & Ephemeroptera $^{\circ}$ & & 30 & & 22 & & 6 & $<0.01$ \\
\hline & Terrestrial Plant * & & 29 & & 33 & & 9 & 0.03 \\
\hline
\end{tabular}

lands, which provide habitats for different fish species. Thus, biotopes upstream of the Branca waterfall and downstream of it differed. The diet of the fish at these sites was probably influenced by the local availability of food resources of allochthonous origin, due to the use of the environment and the characteristics of the channel. Fish in the section upstream of the Branca Waterfall consumed more seeds, hymenopterans and terrestrial plants (leaves) in the rainy period. During this period an increase in the supply of allochthonous resources is expected, since it coincides with the greatest reproductive activity of terrestrial insects (GALINA \& HAHN 2004) and fruiting and dispersal of many plants of the Cerrado (Pirani et al. 2009), which are carried to the aquatic environments (SouzA-Stevaux et al. 1994, CASSEmiro et al. 2002). In the dry period, there was an increase in plant consumption in this and other biotopes, since during this period most of the deciduous species in the region lose their leaves (PIRANi et al. 2009). In the downstream stretch of the Branca Waterfall, characterized by surroundings predominantly composed of pasture, we observed an increase in the consumption of species of Isoptera and Coleoptera in the rainy period. In pastures, mainly in the Cerrado region, termite colonies (VALÉrIo 2006, Oliveira et al. 2011), and dung beetles (KolLer et al. 2007) are common. During heavy rainfall these insects are carried by runoff into the water bodies. Thereby, the characteristics of the surroundings were important in differentiating the diet composition of species between the biotopes analyzed, because they undergo different changes in relation to seasonality.

Resource use by fish in the biotopes in the Verde River was also different from those in the tributary. The differences may be related to characteristics often attributed to tributary rivers, which are smaller and have more preserved riparian vegetation, and physical, chemical and structural characteristics distinct from the main channel of the drainage basin (RICE et al. 2001, BENDA et al. 2004). In the tributary, the most consumed resources during the rainy period were also of allochthonous origin, for instance seeds, terrestrial plant and insects. Nevertheless, in the dry period there was a significant contribution of the aquatic vegetation, specifically bryophytes, which possibly contributed to the aforementioned differences. In agreement with DAvies et al. (2008), the increased supply of this resource in this period may be related to the lower water level, which provides greater light incidence and thus higher primary production in the environment.

The contribution of allochthonous resources in the diet of species was evident in this study. In the Neotropics, variations over space and time influence especially the supply of allochthonous resources, since they depend on the vegetation phenology and life cycles of invertebrates, as well as their respective inputs to aquatic ecosystems (GIMENEs et al. 2010, SCHNeIder et al. 2011). Features such as the presence of vegetation, combined with seasonal factors, such as changes in water flow, naturally caused by heavy rainfall, sudden drops in temperature and prolonged droughts, intensify the availability of these resources as a source of food to the fish fauna. This explains the significant interaction measured by PERMANOVA between the spatial and seasonal factors.

Differences in resource utilization due to spatial and temporal variations contributed to the low dietary overlap between small fish species. Furthermore, the result of the null model suggests that resource partitioning is occurring between the species studied, which supports the results of several studies in Neotropical environments (Mérona \& RANKIn-De-Mérona 2004, Russo et al. 2004, NovaKowski et al. 2008, Brasil-Souza et al. 2009, CorrêA et al. 2009, 2011, Alves et al. 2011, Silva et al. 2012). The use of resources at different spatial and temporal scales, and different strategies to obtain food, favor resource partitioning, and therefore a lower overlap in resource utilization among different species. According to Ross (1986), the partitioning of food resources in more heterogeneous sites, where different types of food resources are available, is one of the main mechanisms of trophic segregation, and consequently, species coexistence.

We conclude that spatial and seasonal changes occurred in the use of food resources by small fish species. Spatial variations are related to physiographic differences of the channel and surroundings, which influence the availability of distinct items among the different biotopes. This different spatial heterogeneity contributes to the significance of temporal changes 
in diet, also reflecting in the low dietary overlap between species. Thus, it becomes evident that the interaction between spatial and temporal factors explain the results obtained in this study.

We emphasize that this type of ecological information is of great value when developing conservation strategies and is, therefore, a key element in the protection of species and ecosystems, especially when it comes to the current scenario, with the establishment of dams in the region, which would affect the relationships found here differently.

\section{ACKNOWLEDGMENTS}

We thank the Reasearch Group in Fishing Resources and Limnology (GERPEL) for their help in fieldwork. Eletrosul Centrais Elétricas S.A. funded our research. Capes granted us a research fellowship. E.A. Gubiani receives a scientific productivity fellowship from the CNPq (process 302143/2011-4) and acknowledges this agency for the grants received.

\section{LITERATURE CITED}

Abelha, M.C.F.; A.A. Agostinho \& E. Goulart. 2001. Plasticidade trófica em peixes de água doce. Acta Scientiarum 23: 425434.

Abujanra, F.; A.A. Agostinho \& N.S. Hahn. 2009. Effects of the flood regime on the body condition of fish of different trophic guilds in the Upper Paraná River floodplain, Brazil. Brazilian Journal of Biology 69 (2): 469-479. doi: 10.1590/ S1519-69842009000300003

Ahrens, R.N.M.; C.J. Walters \& V. Christensen. 2012. Foraging arena theory. Fish and Fisheries 13: 41-59. doi: 10.1111/ j.1467-2979.2011.00432.x

Alves, G.H.Z.; R.M. Tófoli; G.C. NovaKowski \& N.S. HaHn. 2011. Food partitioning between sympatric species of Serrapinnus (Osteichthyes, Cheirodontinae) in a tropical stream. Acta Scientiarum. Biological Sciences 33: 153-159. doi: 10.4025/ actascibiolsci.v33i2.7593

Anderson, M.J. 2001. A new method for non-parametric multivariate analysis of variance. Austral Ecology 26: 3246. doi: 10.1111/j.1442-9993.2001.01070.pp.x

Angermeier, P.L. 1982. Resource seasonality and fish diets in an Illinois stream. Environmental Biology of Fishes 7(3): 251264. doi: 10.1007/BF00002500

Avma Panel on euthanasia. 2001. Report of the Avma panel on euthanasia. Journal of the American Veterinary Medical Association 218 (5): 669-696. doi: 10.1016/0892-0362(92)90004-T

Benda, L.; N.L. PofF; D. Miller; T. Dunne; G. Reeves; G. Pess \& M. Pollock. 2004. The network dynamics hypothesis: how channel networks structure riverine habitats. BioScience 54 (5): 413-427. doi: 10.1641/0006-3568(2004)054[0413:TNDHHC]2.0.CO;2

Bennemann, S.T.; W. Galves \& L.G. Capra. 2011. Recursos alimentares utilizados pelos peixes e estrutura trófica de quatro trechos no reservatório Capivara (Rio Paranapanema). Biota Neotropica 11: 63-71. doi: 10.1590/S1676-06032011000100006

BERG, M.P. \& J. BENGTSSON. 2007. Temporal and spatial variability in soil food web structure. Oikos 116: 1789-1804. doi: 10.1111/j.0030-1299.2007.15748.x

Bicudo, C.E.M. \& R.M.T. Bicudo. 1970. Algas de águas continentais brasileiras chave ilustrada para identificação de gêneros. São Paulo, Fundação Brasileira para o Desenvolvimento do Ensino de Ciências, 227p.

Borcard, D.; F. Gillet \& P. Legendre. 2011. Numerical Ecology with R. New York, Springer, 302p.

Brazil-Sousa, C.; R.M. Marques \& M.P. Albrecht. 2009. Segregação alimentar entre duas espécies de Heptapteridae no Rio Macaé, RJ. Biota Neotropica 9: 31-37. doi: 10.1590/S167606032009000300002

Brose, U.; M. Pavão-Zuckerman; A. EklöF; J. Bengtsson; M.P. Berg; S.H. Cousins; C. Mulder; H.A. Verhoef \& V. Wolters. 2005. Spatial aspects of food webs, p. 463-470. In: P.C. DE RUITER; V. Wolters \& J.C. Moore (Eds). Dynamic Food Webs: Multispecies assemblages, ecosystem development and environmental change. San Diego, Academic Press, 590p.

Cassemiro, F.A.S.; N.S. Hahn \& R. Fugr. 2002. Avaliação da dieta de Astyanax altiparanae Garutti \& Britski, 2000 (Osteichthyes, Tetragonopterinae) antes e após a formação do reservatório de Salto Caxias, Estado do Paraná, Brasil. Acta Scientiarum Biological Sciences 24 (2): 419-425.

CorrêA, C.E.; A.C. Petry \& N.S. Hahn. 2009. Influência do ciclo hidrológico na dieta e estrutura trófica da ictiofauna do rio Cuiabá, Pantanal Mato-Grossense. Iheringia, Série Zoologica 99 (4): 456-463. doi: 10.1590/S0073-47212009000400018

CorrêA, C.E; M.P. Albrecht \& N.S. Hahn. 2011. Patterns of niche breadth and feeding overlap of the fish fauna in the seasonal Brazilian Pantanal, Cuiabá River basin. Neotropical Ichthyology 9 (3): 637-646. doi: 10.1590/S1679-62252008000400004

Castro, R.M.C.; L. Casatti; H.F. Santos; K.M. Ferreira; A.C. Ribeiro; R.C. Benine; G.Z.P. Dardis; A.L.A. Melo; R. Stopiglia; T.X. Abreu; F.A. Bockmann; M. Carvalho; F.Z. Gibran \& F.C.T. Lima. 2003. Estrutura e composição da ictiofauna de riachos do rio Paranapanema, sudeste e sul do Brasil. Biota Neotropica 3 (1): 01-14. doi: 10.1590/S1676-06032003000100007

Davies, P.M.; S.E. Bunn \& S.K. Hamilton. 2008. Primary production in tropical streams and rivers, p. 23-42. In: D. Dudgeon (Ed.). Tropical stream ecology. Oxford, Elsevier, 370p.

Dufrêne, M. \& P. Legendre. 1997. Species assemblages and indicator species: the need for a flexible asymmetrical approach. Ecological Monographs 67: 345-366. doi: 10.1890/0012-9615(1997)067[0345:SAAIST]2.0.CO;2

Esteves, K. \& E.P.M. Galetti JR. 1995. Food partitioning among some characids of a small Brazilian floodplain lake from the Paraná River basin. Environmental Biology of Fishes 42: 375-389. doi: 10.1007/bf00001468

Galina, A.B. \& N.S. HAHN. 2004. Atividade de forrageamento de Triportheus spp. (Characidae, Triportheinae) utilizada como 
ferramenta de amostragem da entomofauna, na área do reservatório de Manso, MT. Revista Brasileira de Zoociências 6 (1): 81-92.

Gerking, S.D. 1994. Feeding ecology of fishes. San Diego, Academic Press, $416 \mathrm{p}$.

Gimenes, K.Z.; M.B. Cunha-Santino \& I. Bianchini Jr. 2010. Decomposição de matéria orgânica alóctone e autóctone em ecossistemas aquáticos. Oecologia Australis 14 (4): 10361073. doi: $10.4257 /$ oeco.2010.1404.13

GotelLI, N.J. \& ENTSMINGER, G.L. 2006. EcoSim: nullmodels software for ecology. Jericho, Acquired Intelligence Inc., Kesey-Bear, version 7. Available online at: http://www.garyentsminger.com/ ecosim/index.htm

Graça, W.J. \& C.S. Pavanelli. 2007. Peixes da planície de inundação do alto rio Paraná e áreas adjacentes. Maringá, EDUEM, 241p.

Grossman, G.D. 1986. Food resources partitioning in a rocky intertidal fish assemblage. Journal of Zoology 1: 317-355. doi: 10.1111/j.1096-3642.1986.tb00642.x

Gubiani, E.A.; L.C. Gomes; A.A. Agostinho \& G. Baumgartner. 2010. Variations in fish assemblages in a tributary of the Upper Paraná River, Brazil: a comparison between pre and postclosure phases of dams. River Research and Applications 26: 848-865. doi: 10.1002/rra.1298

HAHN, N.S. \& R. Fugi. 2007. Alimentação de peixes em reservatórios brasileiros: alterações e consequências nos estágios iniciais do represamento. Oecologia Brasiliensis 11: 469-480.

Hahn, N. S.; I.F. Adrian; R. Fugi \&V. L.L. Almeida. 1997. Ecologia trófica, p. 209-228. In: A.E.A.M. VAzzoler,; A.A. Agostinho \& N. S. HAHn (Eds). A planície de inundação do alto rio Paraná: aspectos físicos, biológicos e socioeconômicos. Maringá, EDUEM, 460p.

Harvey, P.H.; R.K. Colwell; J.W. Silvertown \& R.M. May. 1983. Null models in ecology. Annual Review of Ecology and Systematics 14: 189-211.

Hellawell, J.M. \& R.A. Abel. 1971. Rapid volumetric method for the analysis of the food of fishes. Journal of Fish Biology 3: 29-37. doi: 10.1111/j.1095-8649.1971.tb05903.x

Hyslop, E.J. 1980. Stomach contents analysis: a review of methods and their application. Journal of Fish Biology 17: 411-429. doi: 10.1111/j.1095-8649.1980.tb02775.x

HoLT, R.D. 2002. Food webs in space: On the interplay of dynamic instability and spatial processes. Ecological Research 17: 261273. doi: 10.1046/j.1440-1703.2002.00485.x

Jongman, R.H.G.; C.J.F. Ter BraAk \& O.F.R. Van Tongeren. 1995. Data analysis in community and landscape ecology. Cambridge, Cambridge University Press, 212p.

Koller, W.W.; A. Gomes; S.R. Rodrigues \& P.F.I. Goiozo. 2007. Sacarabaeidae e Aphodiidae coprófagos em pastagens cultivadas em área do Cerrado sul-mato-grossense. Revista Brasileira de Zoociências 9 (1): 81-93.

LEgendRe, P. \& L. LegendRE. 1998. Numerical ecology. Amsterdam, Elsevier, 1006p.
Lima-Junior, S. E. \& R. Goitein. 2004. Diet and feeding activity of Pimelodus maculates (Osteichthyes, Pimelodidae) in the Piracicaba River (State of São Paulo, Brazil) - the effect of seasonality. Boletim do instituto de Pesca 30 (2): 135-140.

Lowe-McConnel, R.H. 1999. Estudos ecológicos de comunidade de peixes tropicais. São Paulo, EDUSP, 535p.

MANLY, B.F.J. 1994. Multivariate statistical methods: a primer. London, Chapman \& Hall, 224p.

Masdeu, M.; F.T. Mello; M. L. \& M. Arim. 2011. Feeding habits and morphometry of Iheringichthys labrosus (Lütken, 1874) in the Uruguay River (Uruguay). Neotropical Ichthyology 9 (3): 657-664. doi: 10.1590/S1679-62252011005000034

McCune, B. \& M.J. MefFord. 2006. PC-ORD, version 5.0, Multivariate analysis of ecological data. Gleneden Beach, MjM Solfware Desing. 40p.

Mérona, B. \& J. Rankin-de-Mérona. 2004. Food resource partitioning in a fish community of the central Amazon floodplain. Neotropical Ichthyology 2 (2): 75-84. doi: 10.1590/S1679-62252004000200004

Mugnai, R.; J.L. Nessimian \& D.F. BAPTISTA. 2010. Manual de identificação de macroinvertebrados aquáticos do Estado do Rio de Janeiro. Rio de Janeiro, Technical Boocks, 174p.

Novakowski, G.C.; N.S. Hahn \& R. Fugr. 2008. Diet seasonality and food overlap of the fish assemblage in a pantanal pond. Neotropical Ichthyology 6: 567-576. doi: 10.1590/S167962252008000400004

Oliveira, M.I.L.; D. Brunet; D. Mitja; W.S. Cardoso; N.P. Bentto; M.F. GUIMARÃES \& M. BROSSARD. 2011. Incidence of epigeal nest-building termites in Brachiaria pastures in the Cerrado. Acta Scientiarum 33 (1): 181-185. doi: 10.4025/actasciagron.v33i1.7075

Pagotto, C.S. \& P.R. Souza. 2006. Biodiversidade do Complexo Aporé-Sucuriú: subsídios à conservação e ao manejo do Cerrado: área prioritária 316-Jauru. Campo Grande, UFMS, 308p.

Perry, J.A. \& D.J. schaeffer. 1987. The longitudinal distribution of riverine benthos: A river discontinuum? Hydrobiologia 148 (3): 257-268. doi: 10.1007/BF00017528

PetTIT, N.E.; P. Bayliss; P.M.Davies; S.K.Hamilton; D.M.Warfe; S.E.BunN $\&$ M.M. DougLas. 2011. Seasonal contrasts in carbon resources and ecological processes on a tropical ûoodplain. Freshwater Biology 56: 1047-1064. doi: 10.1111/j.1365-2427.2010.02544.x

PiAnKA, E.R. 1973. The structure of lizard communities. Annual Review of Ecology and Systematics 4: 53-74. doi: 10.1146/ annurev.es.04.110173.000413

Pirani, F.R.; M. Sanchez \& F. Pedroni. 2009. Fenologia de uma comunidade arbórea em cerrado sentido restrito, Barra do Garças, MT, Brasil. Acta Botanica Brasilica 23 (4): 10961109. doi: 10.1590/S0102-33062009000400019

Prejs, A. \& K. Prejs. 1987. Feeding of tropical freshwater fishes: seasonality in resource availability and resource use. Oecologia 71: 97-404. doi: 10.1007/BF00378713

Polis G.A.; R.D. Holt; B.A. Menge \& K. Winemiller. 1996. Time, space and life history: inûuences on food webs. Food Web. 435-460. doi: 10.1007/978-1-4615-7007-3_38 
Polis, G.A.; W.B. Anderson \& R.D. Holt. 1997. Toward an integration of landscape and food web ecology: The dynamics of spatially subsidized food webs. Annual Review of Ecology and Systematics 28: 289-316. doi: 10.1146/ annurev.ecolsys.28.1.289

Pombo, M.; M.R. Denadai \& A. Turra. 2013. Seasonality, Dietary Overlap and the Role of Taxonomic Resolution in the Study of the Diet of Three Congeneric Fishes from a Tropical Bay. Plos One 8 (2): 1-10. doi: 10.1371/journal.pone.0056107

R Development Core Team. 2011. R: A language and environment for statistical computing. Vienna, R Foundation for Statistical Computing, ISBN 3-900051-07-0. Available online at: http://www.R-project.org

Ribeiro, J.F. \& B.M.T. Walter. 1998. Fitofisionomias do bioma cerrado, p.89-166. In: S.M. SANo \& S.P. AlmeIda (Eds). Cerrado: ambiente e flora. Planaltina, EMBRAPA-CPAC, XII+556p.

Rice, S.P.; M.T. Greenwood \& C.B. Joyce. 2001. Tributaries, sediment sources, and the longitudinal organization of macroinvertebrate fauna along river systems. Canadian Journal of Fisheries and Aquatic Sciences 58: 828-840.

Ross, S.T. 1986. Resource partitioning in fish assemblages: a review of field studies. Copeia 1986: 352-388.

Russo, M.R.; N.S. Hahn \& C.S. Pavanelli. 2004. Resource partitioning between two species of Bryconamericus Eigenmann, 1907 from the Iguaçu river basin, Brazil. Acta Scientiarum. Biological Sciences 26 (4): 431-436.

Schneider, M.; P.P.U. Aquino; M.J.M. Silva \& C.P. Fonseca. 2011. Trophic structure of a fish community in Bananal stream subbasin in Brasília National Park, Cerrado biome (Brazilian Savanna), DF. Neotropical Ichthyology 9: 579-592. doi: 10.1590/S1679-62252011005000030

Schoener, T.W. 1989. Food webs from the small to the large. Ecology 70: 1559-1589. doi: org/10.2307/1938088

Silva, J.C.; R.L. Delariva \& K.O. Bonato. 2012. Food-resource partitioning among fish species from a first-order stream in northwestern Paraná, Brazil. Neotropical Ichthyology 10 (2): 389-399.

Souza-Stevaux, M.C.; R.R.B. Negrelle \& V. Citadini-Zanette. 1994. Seed dispersal by the fish Pterodoras granulosus in the Paraná River Basin, Brazil. Journal of Tropical Ecology 10: 621626.

StATSOFt, Inc. 2005. Statistica: data analysis software system. Version 7.1. Available online at: www.statsoft.com
Uieda, V.S. \& T.L.F. Pinto. 2011. Feeding selectivity of ichthyofauna in a tropical stream: space-time variations in trophic plasticity. Community Ecology 12: 31-39. doi: 10.1556/ComEc.12.2011.1.5

VALÉrIo, J.R. 2006. Cupins-de-montículo em pastagens. Campo Grande, Embrapa, 33p.

Vannote, R.L.; G.W. Minshall; K.W. Cummins; J.R. Sedell \& C.E. Cushing. 1980. The river continuum concept. Canadian Journal of Fisheries and Aquatic Sciences 37: 130-137. doi: 10.1139/f80-017

Viana, L.F.; S.L. SANTos \& S.E. Lima-Junior. 2006. Variação sazonal na alimentação de Pimelodella cf. gracilis (Osteichthyes, Siluriformes, Pimelodidae) no rio Amambai, Estado de Mato Grosso do Sul. Acta Scientiarum. Biological Sciences 28 (2): 123-128. doi: 10.4025/actascibiolsci.v28i2.1028

VianA, L.F.; Y.R. SÚAREZ \& S.E. LIMA-Junior. 2013. Influence of environmental integrity on the feeding biology of Astyanax altiparanae Garutti \& Britski, 2000 in the Ivinhema river basin. Acta Scientiarum. Biological Sciences 35 (4): 541548. doi: 10.4025/actascibiolsci.v35i4.19497

Yang, L.H.; J.L. Bastow; K.O. Spence \& A.N. Wright. 2008. What can we learn from resource pulses? Ecology 89 (3): 621-634.

Winemiller, K.O. \& D.B. Jepsen. 1998. Effects of seasonality and ûsh movement on tropical river food webs. Journal of Fish Biology 53: 267-296. doi: 10.1111/j.1095-8649.1998.tb01032.x

Winemiller, K.O. \& E.R. PianKa. 1990. Organization in natural assemblages of desert lizards and tropical fishes. Ecological Monographs 60: 27-55. doi.org/10.2307/1943025

Winemiller, K.O. \& L.C.K. Winemiller. 2003. Food habits of tilapiine cichlids of the Upper Zambezi River and floodplains during the descending phase of the hydrological cycle. Journal of Fish Biology 63: 120-128. doi: 10.1046/j.10958649.2003.00134.x

WolfF, L.L.; N. Carniatto \& N.S. Hahn. 2013. Longitudinal use of feeding resources and distribution of fish trophic guilds in a coastal Atlantic stream, southern Brazil. Neotropical Ichthyology 11 (2): 375-386. doi: 10.1590/S167962252013005000005

ZARET, T.M. \& A.S. RAND. 1971. Competition in tropical stream fishes: support for the competitive exclusion principle. Ecology 52: 336-342. doi: 10.2307/1934593

ZAVALA-CAMIN, L.A. 1996. Introdução aos estudos sobre alimentação natural em peixes. Maringá, Eduem/Nupelia, 129p.

Submitted: 30.X.2013; Accepted: 16.IX.2014.

Editorial responsibility: Vinicius Abilhoa 
Appendix S1. Food items consumed by the fish fauna in Verde River and its tributary, Upper Paraná River Basin, Mato Grosso do Sul State, Brazil. Values based on data for volume percentage of the food item. The most consumed food items are in bold. Asterisk indicates values less than 0.1\%. (Afa) A. aff. fasciatus, (Apa) A. aff. paranae, (Aal) A. altiparanae, (Ade) A. dentatus, (Bst) B. stramineus, (Bry) Bryconamericus sp. 1, (Kmo) K. moenkhausii, (Min) M. aff. intermedia, (Msa) M. aff. sanctaefilomenae, (Par) P. argentea, (Pgr) P. gracilis, (Sno) S. notomelas.

\begin{tabular}{|c|c|c|c|c|c|c|c|c|c|c|c|c|}
\hline Food items/Species & Afa & Apa & Aal & Ade & Bst & Bry & Kmo & Min & Msa & Par & Pgr & Sno \\
\hline \multicolumn{13}{|l|}{ Autochthonous } \\
\hline Testate Amoebae & & & & * & * & & & & * & * & * & \\
\hline Acarina & * & & * & & & & & * & & * & & * \\
\hline Amphipoda & & & & & & & & & & * & & \\
\hline Cladocera & & & 0.1 & & & & & & & & & \\
\hline Ostracoda & & & & & * & & & * & & & & \\
\hline Ephemeroptera & 0.7 & 0.9 & 0.3 & 17.3 & 5.2 & 5.1 & 1.4 & 15.2 & & 1.6 & 0.3 & 0.8 \\
\hline Immature Coleoptera & 0.1 & 0.7 & 0.1 & & 0.7 & 0.7 & 0.7 & 1.7 & & 0.6 & 0.6 & * \\
\hline Immature Lepidoptera & 0.2 & & 0.3 & & 0.3 & 0.3 & 1.0 & 0.6 & 4.1 & 0.3 & 0.3 & \\
\hline Immature Diptera & 0.1 & & * & 20.7 & 6.4 & 2.0 & 8.9 & 16.1 & 0.2 & 1.0 & 1.0 & 1.1 \\
\hline Odonata nymph & 2.2 & & 0.7 & 3.5 & 4.3 & 3.0 & 0.1 & 1.7 & 0.2 & 1.7 & 5.0 & 0.5 \\
\hline Plecoptera & 0.6 & 0.7 & 0.2 & & 6.1 & 2.6 & 0.5 & 2.0 & & 1.0 & 0.2 & 0.1 \\
\hline Trichoptera & 0.6 & 0.3 & 0.1 & 9.5 & 5.5 & 5.2 & 2.0 & 3.6 & 1.6 & 6.2 & 3.0 & 1.0 \\
\hline Aquatic insect remains & 2.0 & 1.8 & 0.7 & 19.0 & 11.9 & 5.3 & 1.6 & 11.0 & 4.3 & 2.7 & 1.6 & 1.3 \\
\hline Scales & 0.1 & & 0.9 & 7.1 & 0.2 & 0.2 & 0.1 & * & * & 0.3 & 9.9 & * \\
\hline Fish & 0.1 & & 0.7 & & & * & & & & 0.1 & 3.0 & \\
\hline Algae & 4.1 & 1.9 & 3.0 & & & * & 4.0 & 0.5 & 0.2 & 0.2 & & 45.2 \\
\hline Aquatic plant & 5.2 & & 1.2 & & * & 0.1 & 2.6 & 0.4 & & 0.7 & 1.7 & 2.9 \\
\hline \multicolumn{13}{|l|}{ Allochthonous } \\
\hline Oligochaeta & 0.4 & & 4.1 & & & & & & & & 4.2 & \\
\hline Coleoptera & 4.2 & 5.0 & 8.8 & 8.0 & 3.5 & 4.0 & 1.6 & 1.5 & 16.7 & 2.7 & 0.9 & * \\
\hline Araneae & * & 0.2 & 1.0 & & 0.6 & 0.2 & 0.4 & 0.6 & 0.2 & 0.5 & & 0.1 \\
\hline Diptera & * & & 0.2 & 0.2 & 0.4 & 0.3 & 0.1 & 0.5 & & * & * & \\
\hline Hemiptera & 3.0 & & 2.2 & 2.2 & 0.8 & 1.4 & 0.4 & 1.6 & 0.4 & 1.4 & 0.1 & \\
\hline Homoptera & 0.1 & & 0.1 & & * & * & * & 0.1 & & 0.1 & & \\
\hline Hymenoptera & 20.9 & 9.4 & 18.4 & 2.6 & 14.8 & 8.5 & 6.7 & 12.9 & 57.2 & 6.7 & 3.8 & * \\
\hline Isoptera & 0.7 & 1.1 & 4.9 & & 11.0 & 3.6 & 5.7 & 9.9 & 1.2 & 0.5 & 0.1 & \\
\hline Orthoptera & 2.7 & & 0.9 & & 0.1 & & 0.1 & & & 0.3 & & \\
\hline Psocoptera & * & 4.1 & * & & 0.2 & * & & 4.6 & & & & \\
\hline Terrestrial insect remains & 2.3 & 0.2 & 0.8 & 1.7 & 0.9 & 1.2 & 0.4 & 1.9 & 1.6 & 1.9 & & 0.1 \\
\hline Seeds & 28.6 & 9.7 & 41.2 & & 20.8 & 47.9 & 46.1 & 8.7 & & 62.6 & 59.5 & 4.3 \\
\hline Terrestrial Plant & 20.7 & 64.1 & 9.4 & 1.3 & 5.9 & 8.3 & 15.3 & 4.8 & 12.3 & 6.4 & 4.7 & 19.0 \\
\hline \multicolumn{13}{|l|}{ Undetermined } \\
\hline Detritus & 0.2 & & * & 6.9 & 0.3 & & 0.3 & & & 0.4 & 0.1 & 24.0 \\
\hline
\end{tabular}

